\title{
Pelatihan dan Simulasi IELTS bagi Mahasiswa dan Dosen di Lingkungan Fakultas Pendidikan dan Keguruan Program Studi Bahasa Inggris Universitas Widya Gama Mahakam Samarinda
}

\author{
Rinda Fitriana \\ Universitas Widya Gama Mahakam Samarinda \\ rindming@gmail.com \\ Dedi Rahman Nur \\ Universitas Widya Gama Mahakam Samarinda \\ d.blues84@gmail.com \\ Arbain \\ Universitas Widya Gama Mahakam Samarinda \\ baintigers@gmail.com
}

\begin{abstract}
Abstrak
IELTS (International English Language Testing System) merupakan tes kecakapan Bahasa Inggris terstandar yang menjadi prasyarat untuk melanjutkan studi atau berkerja di luar negeri. Penting bagi Mahasiswa dan Dosen FKIP Bahasa Inggris di Universitas Widya Gama Mahakam untuk mengetahui tes IELTS ini, mempertimbangkan kebutuhan mereka untuk melanjutkan studi dan atau berkerja di luar negeri. Hasil tes IELTS ini dapat diterima di hampir seluruh Negara. Namun, karena tingkat kesulitan tes ini cukup tinggi begitu pula dengan biaya mengikuti tes ini, maka diperlukan persiapan yang matang sebelum mengambil tes IELTS. Oleh karena itu, pelatihan ini dilaksanakan untuk merespon kebutuhan siswa dan dosen dalam perkenalan dan persiapan untuk mengambil tes IELTS.

Kegiatan pengabdian masyarakat ini dilakukan dengan cara menyelengarakan pelatihan dan simulasi yang terbagi dalam dua hari. Hari pertama, tanggal 13 Mei 2017, diperuntukkan bagi mahasiswa FKIP Pendidikan bahasa Inggris, dari jam 9.00 - 14.00. Sementara itu, pelatihan dan simulasi IELTS untuk Dosen FKIP Pendidikan Bahasa Inggris dilaksanakan tanggal 10 Juli 2017, dari jam 8.00 - 16.30. Kedua acara ini dilaksanakan di Ruang Laboratorium Bahasa Universitas Widya Gama Mahakam Samarinda. Jl Wahid Hasyim. Mahasiswa yang terdaftar saat proses registrasi adalah 38 orang, namun yang hadir adalah 28 orang. Sementar itu, untuk peserta Dosen, yang diundang adalah 15 orang, dan yang hadir adalah 5 orang.
\end{abstract}




\section{Jurnal Abdimas Mahakam}

https://journal.uwgm.ac.id/index.php/abdimasmahakam

Online ISSN : 2549-5755

Juni 2017, Vol.1 No. 2

Kegiatan ini berakhir di tanggal 10 Juli 2017. Adapun outcomes berdasarkan hasil simulasi IELTS, rata-rata mahasiswa memperoleh Band 4, sementara para Dosen memperoleh rata-rata Band 5,yang berarti kemampuan kecakapan berbahasa Inggris mahasiswa dan dosen masih memadai namun belum cukup untuk bertahan dalam mengikuti perkuliahan di luar negeri. Dari hasil tes essay, terlihat bahwa Dosen dan Mahasiswa masih memiliki kesulitan dalam membuat Essay akademik dalam waktu terbatas (60 menit). Sehingga, pelatihan khusus untuk memperbaiki keahlian menulis akademis diperlukan tindak lanjut.

Kata Kunci: pelatihan, Simulasi, IELTS

\section{Pendahuluan}

Untuk tes kecakapan berbahasa Inggris, orang-orang lebih mengenal tes TOEFL (Test of English for Foreign Language) dengan tipe ITP (Institutional Test Program). Yang mana, tes ini tidak mengukur kemampuan bahasa Inggris peserta secara komprehensif. Untuk dapat berkerja dan/atau melanjutkan studi diluar negeri, tes kecakapan bahasa Inggris menjadi prasyarat. Saat, hampir semua universitas di luar negeri mempersyaratkan mahasiswanya untuk mengambil test TOEFL iBT atau IELTS. IELTS merupakan singkatan dari International English Language Testing System. IELTS adalah tes internasional dalam kemampuan bahasa inggris yang diselenggarakan oleh Universitas Cambridge, British Council dan IDP Educational Australia. Sementara itu TOEFL iBT adalah tes TOEFL melalui online. Kedua tes ini menguji kemampuan berbahasa Inggris secara komprehensif dalam empat sesi; listening, reading, writing dan speaking. Bedanya adalah, TOEFL IBT dilakukan online sementara IELTS dillakukan offline (paper based).

IELTS terbagi menjadi dua tipe, yaitu General Training ,yang ditujukan untuk orang-orang yang ingin berkerja di luar negeri, dan Academic Training, yaitu ditujukan untuk orang-orang yang akan belajar di luar negeri. Tes IELTS menguji kesiapan peserta untuk menggunakan kemampuan bahasa Inggrisnya untuk bertahan hidup di Negara yang dituju. Untuk Academic Training, tes IELTS merupakan miniature perkuliahan di luar negeri. Oleh karena itu, peserta yang mendapat Band 6.5 dianggap siap untuk bertahan menjadi mahasiswa di universitas yang dituju. Adapun score IELTS disebut Band. Terdiri atas Band 1 sampai 9, dari pengguna Bahasa 


\section{Jurnal Abdimas Mahakam}

https://journal.uwgm.ac.id/index.php/abdimasmahakam

Online ISSN : 2549-5755

Juni 2017, Vol.1 No. 2

Inggris terbatas (Band 1-5) hingga cakap dalam berbahasa Inggris (Band 6-9). Biasanya, universitas-universitas di luar negeri mempersyaratkan Band 5.5 atau 6 sebagai syarat minimal penerimaan. Adapun Negara-negara yang mepersyaratkan IELTS adalah kawasan Eropa dan Australia.

Di Samarinda, tidak banyak mahasiswa dan dosen yang mengenal tes IELTS ini, sementara itu, IELTS menjadi prasayarat bagi Dosen yang ingin melanjutkan S3 di luar negeri dan bagi mahasiswa yang ingin melanjutkan S2 di luar negeri. Tes IELTS terbilang mahal dalam biayanya. Oleh karena itu, membutuhkan persiapan yang benar-benar matang sebelum melakukan tes ini.

Melihat kebutuhan Dosen dan Mahasiswa, khususnya bagi mereka yang memiliki dasar pengetahuan dan kemampuan bahasa Inggris, maka Penulis mengadakan Pelatihan dan simulasi IELTS sebagai langkah awal perkenalan IELTS kepada Dosen dan Mahasiswa Program Studi Bahasa Inggris Universitas Widya Gama Mahakam Samarinda. Sehingga, jika suatu hari mereka berencana untuk mengambil tes ini, mereka tidak terkejut dengan format tes yang cukup jauh berbeda dengan tes TOEFL yang biasanya mereka lakukan. Ditambah lagi, untuk kelas persiapan IELTS juga cukup jarang di Samarinda. Sehingga, pelatihan dan simulasi IELTS ini akan sangat membantu dosen dan mahasiswa dalam mempersiapkan dirinya untuk melanjutkan studi di luar negeri baik melalui jalur beasiswa maupun mandiri.

Tujuan diselenggarakan Pelatihan dan Simulasi IELTS ini adalah; pertama, untuk memperkenalkan IELTS kepada Dosen dan Mahasiswa Universitas Widya Gama Mahakam Samarinda, khususnya untuk program studi Pendidikan Bahasa Inggris. Disamping itu, pelatihan ini juga bertujuan mengembangkan kemampuan akademik Dosen dan Mahasiswa dalam hal kecakapan Bahasa Inggris dan kemampuan menghasilkan essay akademik. Ketiga, pelatihan ini menjadi langkah awal bagi dosen dan mahasiswa yang berminat untuk melanjutkan studi dan/atau berkerja diluar negeri.

\section{Metode}

Kegiatan pengabdian masyarakat ini dilakukan dengan cara menyelengarakan pelatihan dan simulasi yang terbagi dalam dua hari. Hari pertama, tanggal 13 Mei 2017, diperuntukkan bagi mahasiswa FKIP Pendidikan bahasa Inggris, dari jam 9.00 - 14.00. Sementara itu, pelatihan 


\section{Jurnal Abdimas Mahakam}

https://journal.uwgm.ac.id/index.php/abdimasmahakam

Online ISSN : 2549-5755

Juni 2017, Vol.1 No. 2

dan simulasi IELTS untuk Dosen FKIP Pendidikan Bahasa Inggris dilaksanakan tanggal 10 Juli 2017, dari jam 8.00 - 16.30. Kedua acara ini dilaksanakan di Ruang Laboratorium Bahasa Universitas Widya Gama Mahakam Samarinda. J1 Wahid Hasyim.

Mahasiswa yang terdaftar saat proses registrasi adalah 38 orang, namun yang hadir adalah 28 orang. Sementar itu, untuk peserta Dosen, yang diundang adalah 15 orang, dan yang hadir adalah 5 orang.

Pelatihan ini dimulai dengan Perkenalan IELTS itu sendiri, dari tujuan tes IELTS, Negaranegara yang mensyaratkan IELTS, Institusi penyelenggara IELTS, format test hingga deskripsi skor. Setelah sesi perkenalan selesai, peserta pelatihan melakukan simulasi tes IELTS yang berlangsung selama 2.40 menit (diluar tes speaking). Test tersebut mencakup tes Listening (40 menit), Reading (60 menit) dan Writing (60 menit). Simulasi dilakukan diawal untuk mempermudah peserta memiliki bayangan akan tes IELTS sehingga, ketika memasuki sesi pelatihan dan penjelasan strategi mengerjakan IELTS, mereka tidak mengalami kebingungan. Pada sesi 3, Pembicara menjelaskan strategi cara mengerjakan tes IELTS per skill; listening, reading, writing dan speaking. Karena waktu yang tersedia tidak cukup memadai, sehingga untuk tes speaking tidak dilakukan. Oleh karena itu, trainer hanya memberikan contoh wawancara IELTS melalui video dan menjelaskan format pertanyaan serta contoh cara menjawabnya. Sesi terakhir ditutup dengan diskusi dan tanya jawab.

\section{Hasil dan Pembahasan}

Selama pelatihan IELTS, baik mahasiswa maupun dosen merasa terkejut dengan format tes IELTS karena pada umumnya mereka lebih familiar dengan format TOEFL. Dalam pelatihan ini. Hanya tiga keahlian berbahasa Inggris; Listening, Reading, dan Writing yang diujikan. Sementara, untuk keahlian Speaking, tidak dapat diujikan dikarenakan terbatasnya waktu pelaksanaan.

Adapun outcomes berdasarkan hasil simulasi IELTS, rata-rata mahasiswa memperoleh Band 3.66 untuk semua language skill, sebagaimana yang digambarkan grafik dibawah ini; 


\section{Jurnal Abdimas Mahakam}

https://journal.uwgm.ac.id/index.php/abdimasmahakam

Online ISSN : 2549-5755

Juni 2017, Vol.1 No. 2

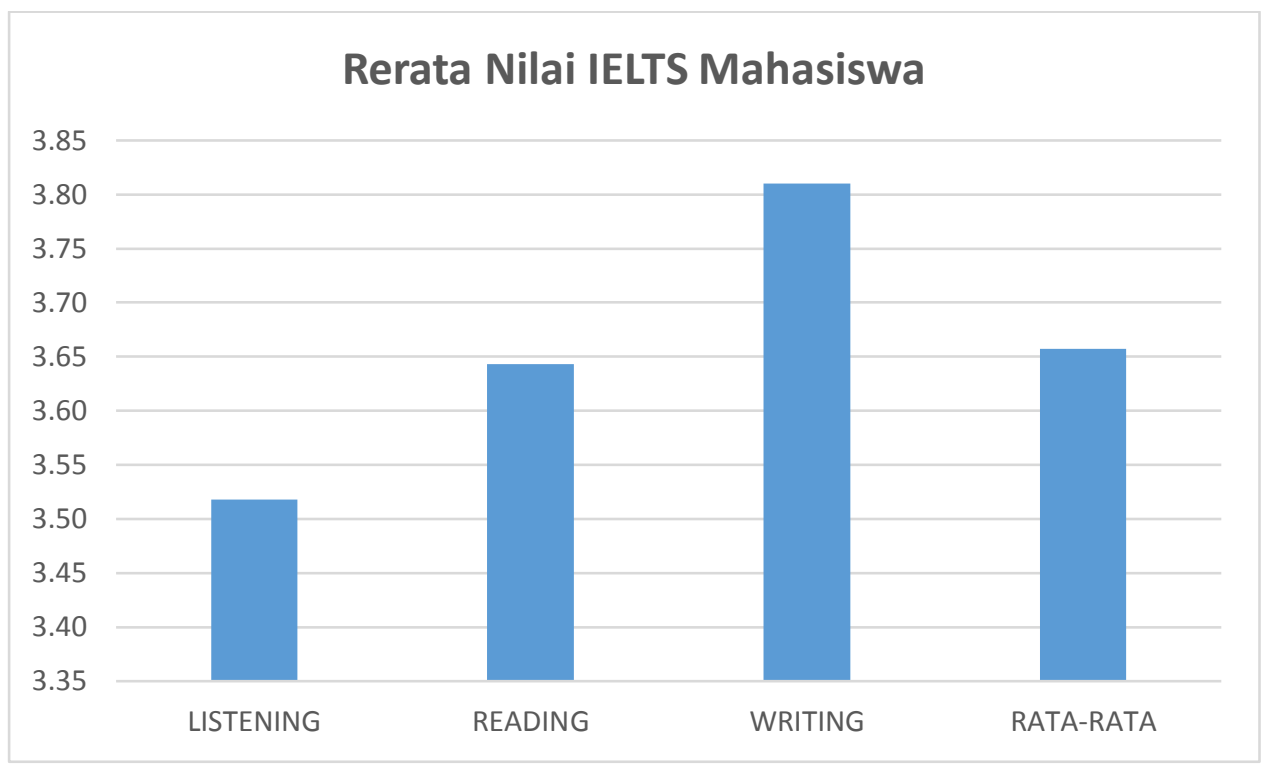

Grafik 1

Rata-rata kemampuan listening mahasiswa berada di skor 3.52, dengan kata lain, kemampuan mahasiswa dalam memahami percakapan lisan dalam konteks akademik masih dapat dikatakan rendah dan diperlukan perbaikan dan lebih banyak latihan. Begitu pula halnya dengan kemampuan reading, rata-rata nilai mahasiswa adalah 3.64 dan kemampuan writing mahasiswa rata-rata mendapatkan nilai 3.81. Karena nilai IELTS yang diperoleh oleh mahasiswa dibawah Band 4, dapat diambil kesimpulan bahwa mahasiswa jurusan Pendidikan Bahasa Inggris di Universitas Widyagama Mahakam Samarinda masih belum memenuhi target dalam konteks akademik. Mahasiswa hanya memiliki kecakapan bahasa Inggris yang terbatas, sehingga tidak memungkinkan bagi mereka untuk berkerja ataupun melanjutkan kuliah di luar negeri.

Sementara itu, para Dosen memperoleh rata-rata Band 5. Untuk kemampuan listening, dosen Bahasa Inggris mendapatkan nilai rata-rata 4.625. Dengan kata lain, kemampuan dosen dalam memahami percakapan dan monologue lisan dalam konteks akademik masih bisa dikatakan standar. Namun, tidak cukup untuk memenuhi persyaratan kuliah di luar negeri. Rata-rata kemampuan reading Dosen berada di Band 5.25. Dalam artian, kemampuan dosen dalam memahami teks akademik dapat dikatakan baik dan memenuhi standar minimal. Sama halnya dengan kemampuan writing, dosen mendapatkan Band 5.375. Secara keseluruhan Dari hasil tes essay, terlihat bahwa Dosen dan Mahasiswa masih memiliki kesulitan dalam membuat Essay akademik dalam waktu terbatas (60 menit). Sehingga, pelatihan khusus untuk 


\section{Jurnal Abdimas Mahakam}

https://journal.uwgm.ac.id/index.php/abdimasmahakam

Online ISSN : 2549-5755

Juni 2017, Vol.1 No. 2

memperbaiki keahlian menulis akademis diperlukan tindak lanjut. Grafik berikut menunjukkan rerata nilai dosen;

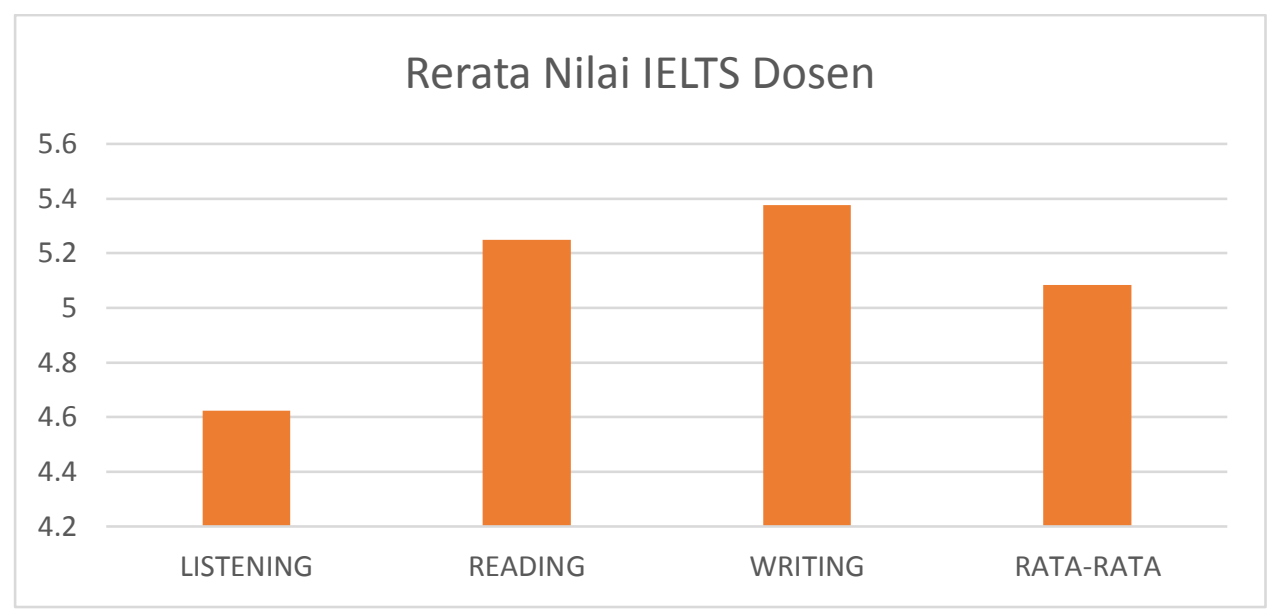

Grafik 2

Berikut adalah perbandingan kemampuan kecakapan berbahasa Inggris antara Dosen dan Mahasiswa berdasarkan hasil skor IELTS.

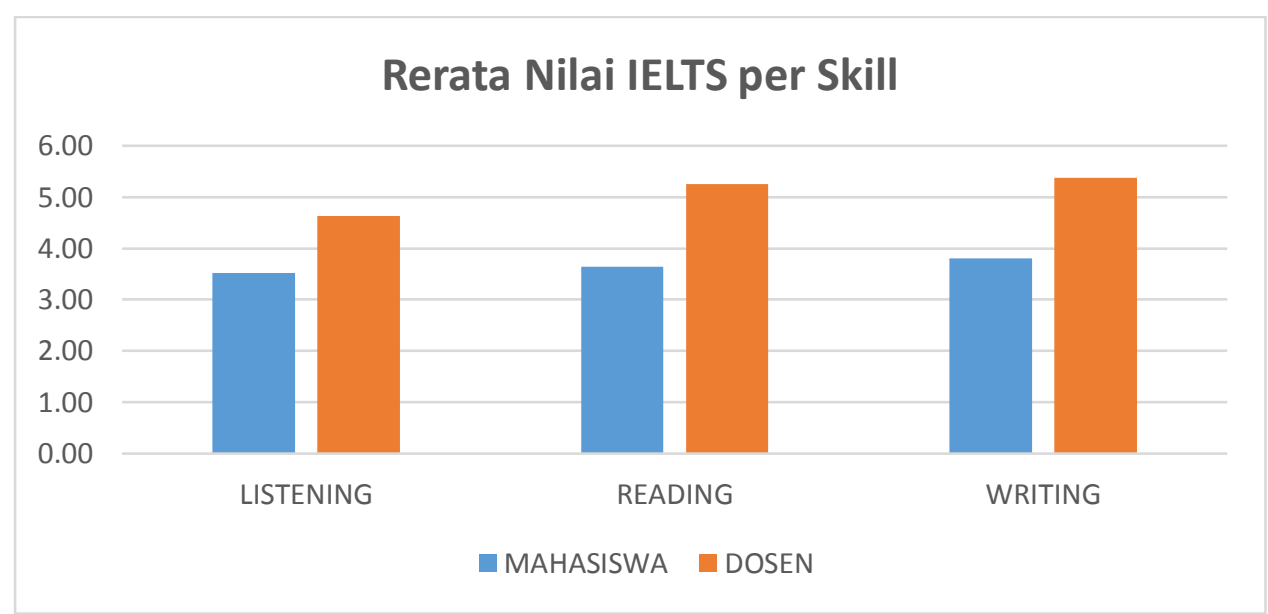

Grafik 3

Terlihat dari grafik diatas, bahwa kemampuan kecakapan berbahasa Inggris Dosen lebih tinggi dari pada mahasiswa. Perbedaan yang mencolok terdapat pada writing skill. 


\section{Jurnal Abdimas Mahakam}

https://journal.uwgm.ac.id/index.php/abdimasmahakam

Online ISSN : 2549-5755

Juni 2017, Vol.1 No. 2

\section{Simpulan dan Rekomendasi}

Kegiatan ini berakhir di tanggal 10 Juli 2017. Adapun outcomes berdasarkan hasil simulasi IELTS, rata-rata mahasiswa memperoleh Band 4, sementara para Dosen memperoleh rata-rata Band 5. Dari hasil tes essay, terlihat bahwa Dosen dan Mahasiswa masih memiliki kesulitan dalam membuat Essay akademik dalam waktu terbatas (60 menit). Sehingga, pelatihan khusus untuk memperbaiki keahlian menulis akademis diperlukan tindak lanjut. 


\section{Jurnal Abdimas Mahakam}

https://journal.uwgm.ac.id/index.php/abdimasmahakam

Online ISSN : 2549-5755

Juni 2017, Vol.1 No. 2

\section{Daftar Pustaka}

Cambridge English. IELTS Academic 11 with Answer. UK: Cambridge English Language Assessment.

Elizabeth. 2017. ieltsliz.com 